Ritrýnd grein birt 31. desember 2021

\title{
Að tilheyra í skólanum: Áhrifapættir á upplifun grunnskólanema
}

\section{Kolbrún P. Pálsdóttir, Kolbeinn Hólmar Stefánsson og Hermína Gunnpórsdóttir}

Abstract $\backslash$ Um höfunda About the authors $>$ Heimildir

Stór áhrifapáttur á farsæld nemenda er að peir upplifi og finni að peir tilheyri skólasamfélaginu og að peim sé tekið eins og peir eru af nemendum og kennurum. Markmið pessarar greinar er að varpa ljósi á hvernig félagslegir pættir líkt og kyn nemenda, fjárhagsstaða og erlendur uppruni móta upplifun peirra af að tilheyra eða tilheyra ekki í skólasamfélaginu. Einnig að kanna hvort áhættuhegðun, samskipti við foreldra og sjálfsmynd hafi áhrif á hvernig félagslegir pættir móta upplifun af að tilheyra. Byggt er á gögnum úr rannsókninni Heilsa og lífskjör skólabarna (HBSC). Rafræn spurningakönnun var lögð fyrir nemendur veturinn 2017-2018 í 6., 8. og 10. bekk. Niðurstöður sýna að almennt séð upplifa nemendur íslenskra grunnskóla að peir tilheyri í skólaumhverfinu og aðeins litlum hópi finnst hann ekki tilheyra. Að búa við slæma fjárhagsstöðu og að skilgreina sig utan hefðbundinnar kyntvíhyggju hefur mest áhrif á að nemendur telji sig síður tilheyra skólasamfélaginu. Ekki mældist marktækur munur almennt séð á milli drengja og stúlkna. Slæm fjárhagsstaða hafði mest áhrif á samsömun kynsegin nemenda og stúlkna við skólasamfélagið, en drengir urðu síður fyrir áhrifum slæmrar fjárhagsstöðu. Pá hafði áhættuhegðun mun sterkari tengsl við tilfinningu drengja að tilheyra fremur en stúlkna, en slök sjálfsmynd stúlkna var frekar tengd upplifun peirra af pví tilheyra ekki. Sterk samvirkni var á milli pess að eiga báða foreldra fædda erlendis og að búa við slæman fjárhag. Öflug sjálfsmynd hafði jákvæð áhrif á samsömun nemenda sem bjuggu við slæma fjárhagsstöðu. Niðurstöður gefa til kynna að grípa purfi til aðgerða til að tryggja aðild allra að skólasamfélaginu og horfa sérstaklega til jaðarsettra nemenda.

Efnisorð: Að tilheyra, upplifun grunnskólanemenda, skólasamfélag, menntun án aðgreiningar, félagsleg samsömun

\section{Inngangur}

Раð аð upplifa að jafnaldrar taki manni eins og maður er, er hluti af að finna til félagslegrar samkenndar og finnast maður tilheyra. Pörfin fyrir að tilheyra er manneskjunni eðlislæg og pað skiptir máli að hver einstaklingur eigi aðild að námssamfélaginu, sé gerandi í eigin lífi (Kolbrún P. Pálsdóttir, 2016). Damon (2008) hefur bent á að ein helsta áskorun nútímasamfélags sé sú að ungmenni upplifi ekki tilgang með athöfnum sínum, ekki síst innan menntakerfisins. Ef rétt reynist pá er petta verulega umhugsunarvert pví pað skiptir okkur öll miklu máli að hafa hlutverk, „... vera kallaður til ákveðinna verka, vera hugsanlega eins og ómissandi við ákveðnar aðstæður" (Páll Skúlason, 2015, bls. 95). Íslensk menntastefna hefur um árabil tekið mið af formerkjum skóla án aðgreiningar (lög um grunnskóla nr. 91/2008) og fyrsta meginstoð nýrrar menntastefnu til 2030 er jöfn tækifæri fyrir alla, sem meðal annars felur í sér að allir nemendur finni sig í menntakerfinu (pingskjal nr. 1111/2020-2021). Markmið pessarar greinar er að varpa ljósi á hvernig prjár mikilvægar 
félagslegar breytur; kyn, uppruni og fjárhagsstaða grunnskólanema, tengjast upplifun peirra að tilheyra eða tilheyra ekki skólasamfélaginu.

Í pessari grein var einkum horft til rannsókna par sem fjallað var um enska hugtakið „belonging“. Sögnin „að tilheyra“ og nafnorð¡ð „samsömun“ er hér notað yfir enska hugtakið „belonging“. Vert er að nefna að hugtakið fullgildi hefur einnig verið notað í pessu samhengi (Jóhanna Einarsdóttir og Sara Margrét Ólafsdóttir, 2020). Á síðari hluta 20. aldar jókst vitund um mikilvægi félagslegrar stöðu og tengslanets nemenda við gengi peirra í skóla. Goodenow og Grady (1993) skilgreindu „school belonging“ sem pá upplifun nemenda að vera „... persónulega sampykkt, virt, viðurkennd og studd af öðrum innan skólans“v . Rannsókn peirra sýndi að bæði uppruni og kyn mótuðu upplifun nemenda af að tilheyra og hafði meðal annars áhrif á námshvata og mat peirra á eigin getu.

Íslenskt samfélag hefur tekið miklum og hröðum breytingum frá aldamótum hvað varðar fjölda nemenda í skólakerfinu sem eru með annan mál- og menningarlegan bakgrunn en íslenskan. Samkvæmt tölum Hagstofu Íslands (e.d.-a) hefur hlutfall innflytjenda á Îslandi aukist frá pví að vera 2,6\% árið 2000 í 15\% árið 2020. Breytt samsetning og bakgrunnur íbúa landsins hefur í för með sér áskorun um að virða hvers konar fjölbreytileika og greiða aðgengi allra að samfélaginu (Banks, 2020). Pá hafa vísbendingar um ólíka stöðu kynjanna innan menntakerfisins kallað á miklar umræður. Á Íslandi eru stúlkur mun líklegri til að meta andlega heilsu sína verr en drengir (Margrét Lilja Guðmundsdóttir o.fl., 2016) en engu að síður virðist drengjum líða verr innan skólans (Ấslaug Pálsdóttir o.fl., 2012). Námsleg staða stúlkna er alla jafna sterkari en drengja (OECD, 2019) og mun fleiri konur sækja sér framhaldsmenntun en karlar (Hagstofa Íslands, e.d.-b). PISA-könnunin er alpjóðleg samanburðarkönnun og beinist að námslegum árangri grunnskólanema, en einnig að skólabrag. Meðal annars er spurt um hve vel/illa svarendur telji sig tilheyra skólasamfélaginu. Í síðustu könnun kom í ljós að í 30 löndum voru drengir líklegri til að upplifa að peir tilheyrðu innan skólans, en í 23 löndum voru stúlkur líklegri til að upplifa að pær tilheyrðu skólasamfélaginu en drengir (OECD, 2019).

Uppruni nemenda og kyn geta pví mótað verulega tengslamyndun og líðan nemenda, en sama á við um fjárhagsstöðu foreldra. Niðurstöður PISA-könnunar sýna að peir nemendur sem búa við skertan fjárhag eru líklegri en jafnaldrar peirra til að finnast peir síður tilheyra innan skólans (OECD, 2019). Fátækt og misskipting hefur aukist á Íslandi og nýleg skýrsla sýnir að fátækt barna hefur aukist verulega frá hruninu árið 2008 (Kolbeinn H. Stefánsson, 2019). Pví er mikilvægt að kanna nánar hvaða áhrif bág fjárhagsstaða hefur á samsömun nemenda innan íslenskra grunnskóla.

Árið 2021 sampykktu stjórnvöld svokölluð farsældarlög en markmið peirra er meðal annars að íslenskt samfélag vinni skipulega að pví að tryggja öllum börnum skilyrði „,... til að ná líkamlegum, sálrænum, vitsmunalegum, siðferðilegum og félagslegum proska og heilsu á eigin forsendum til framtíðar" (lög um sampættingu pjónustu í págu farsældar barna nr. 86/2021). Kerfisbundinn munur á milli hópa getur skipt máli til lengri tíma litið hvað varðar jöfn tækifæri, lífskjör á fullorðinsárum og mannauð fyrir samfélagið almennt. Hér á landi eru lífskjör almennt góð, en pó eru vísbendingar um aukinn ójöfnuð. Nýleg skýrsla um félagstengsl íslenskra ungmenna sýndi að um prjú prósent peirra upplifi lítil tengsl við nærsamfélag sitt og séu verulega illa stödd hvað varðar félagslega stöðu, líðan og framtíðarhorfur (Ársæll Már Arnarsson o.fl., 2020). Pví er rík ástæða til að huga sérstaklega að jaðarhópum í skólakerfinu. Upplifun nemenda af að tilheyra gefur mikilvægar vísbendingar um stöðu peirra innan skólasamfélagsins og endurspeglar ef til vill hvort ungmenni telji sig hafa tilgang innan pess og að pau skipti máli, bæði fyrir samnemendur og starfsfólk skólans.

Í PISA-könnuninni árið 2018 hlaut Ísland pann vafasama heiður að lenda í priðja sæti (á eftir Lúxemborg og Suður-Kóreu) par sem ungmenni sem búa við félagslega skerta stöðu, svo sem innflytjendur og börn sem búa við fátækt, voru mun líklegri en jafnaldrar peirra til að finnast pau ekki tilheyra skólasamfélaginu (OECD, 2019). Mikilvægt er pví að beina sjónum að hvað einkennir stöðuna á Íslandi sérstaklega, par sem að félags- og menningarlegir pættir móta reynslu og upplifun nemenda.

Framlag pessarar greinar er að varpa skýrara ljósi, en áður hefur verið gert, á hvað einkennir stöðuna á Íslandi og að meta hvernig kyn og uppruni nemenda sem og mat peirra á fjárhagsstöðu tengjast upp- 
lifun peirra af að tilheyra skólaumhverfinu. Pá var einnig kannað hvort áhættuhegðun, samskipti við foreldra og sjálfsmynd skýri að einhverju leyti hvernig félagslegir pættir móti upplifun af að tilheyra. Með pessu fæst skýrari mynd af ástæðum pess að nemendur upplifi sig utangarðs í skólasamfélaginu. Pær upplýsingar skipta miklu máli til að hægt sé að móta vinnulag og inngrip innan skólanna sem henta ólíkum hópum og einstaklingum. Leitað var svara við eftirfarandi meginrannsóknarspurningu:

- Hvernig móta kyn, uppruni nemenda og mat peirra á fjárhagsstöðu fjölskyldu sinnar upplifun peirra af að tilheyra í skólasamfélaginu?

- Undirspurning: Hvaða áhrif hafa áhættuhegðun, samskipti við foreldra og sjálfsmynd nemenda á tengsl félagslegra pátta, s.s. kyns, uppruna og fjárhagsstöðu, við upplifun peirra af að tilheyra?

\section{Staða pekkingar}

Rannsóknir sem hverfast um „belonging“ benda til pess að nemendum, sem hafa sterka tilfinningu fyrir að peir tilheyri skólasamfélaginu, gangi alla jafna betur námslega og hafi sterkari stöðu en peir sem upplifa sig jaðarsetta, til dæmis varðandi áhuga á skólanum, sjálfsmynd, hegðun í bekknum og námsárangur en neikvæð upplifun tengist til dæmis brotthvarfi úr skóla (Christenson og Reschly, 2010; Korpershoek o.fl., 2020; OECD, 2019). Peir nemendur sem upplifa síður að peir tilheyri hópum eða samfélagi eru í meiri hættu á verða fyrir neikvæðum félagslegum áhrifum, eru líklegri til að hafa lágt sjálfsmat og pjást af kvíða og punglyndi (Allen o.fl., 2018; Gillen-O’Neel og Fuligni, 2013).

Félagsleg samsömun og tengsl við samnemendur og kennara geta mótað hugmyndir nemenda um hvað peir telja sig geta gert og hvaða árangri peir munu ná í menntakerfinu. Íslenskar rannsóknir á námsárangri, líðan og brotthvarfi hafa vel flestar fjallað um áhrifapætti á borð við námslega og félagslega skuldbindingu nemenda, tengsl peirra við foreldra sína og félagslega stöðu peirra almennt (Kristjana Stella Blöndal og Atli Hafpórsson, 2018). Alpjóðlega efnahags- og framfarastofnunin hefur einnig sýnt fram á að pað eru jákvæð tengsl á milli pess að nemendur upplifi sig tilheyra innan skólans og árangurs í læsi (OECD, 2019). Pví er ljóst að pað getur skipt miklu máli að vinna gegn pví að nemendur upplifi sig jaðarsetta til að stuðla að jafnrétti og efla velferð peirra og námsgengi.

Bæði íslenskar og erlendar rannsóknir hafa sýnt að nemendum af erlendum uppruna er hætt við að verða jaðarsettir í skóla og samfélagi (Borraccino o.fl., 2020; Hanna Ragnarsdóttir og Fríða B. Jónsdóttir, 2016; Nieto, 2010). Í nýlegri rannsókn (Hermína Gunnpórsdóttir og Lilja Rós Aradóttir, 2021) voru tekin viðtöl við ungmenni af erlendum uppruna og rauður práður í niðurstöðunum var einlægur vilji nemendanna til að verða hluti af pví samfélagi sem peir tilheyra, par sem peim líður vel og peir sjá framtíð sína. Peir upplifa hins vegar margar hindranir, bæði félagslegar og námslegar, og vísbendingar eru um að sá stuðningur sem pau fá frá skólanum gagnist peim illa við að mynda félagsleg tengsl. Margt í niðurstöðunum bendir til að nemendurnir séu í aukinni áhættu á að upplifa einangrun (e. marginality) eða jafnvel aðskilnað (e. separation) frá samfélaginu.

Slæm efnahagsleg staða fjölskyldu og fátækt getur einnig haft umtalsverð áhrif á menntun og námsgengi barna. Niðurstöður PISA-könnunar sýna að peir nemendur sem búa við skertan fjárhag eru líklegri en jafnaldrar peirra til að finnast peir síður tilheyra innan skólans (OECD, 2019). Nýleg íslensk rannsókn leiddi í ljós að peir grunnskólanemar sem búa við skertan fjárhag upplifa mun frekar andlega og líkamlega vanlíðan (Ársæll Már Arnarsson o.fl., 2019) og önnur íslensk langtímarannsókn sýndi fram á að slæmur fjárhagur fjölskyldu er einn af peim páttum sem geta haft áhrif á námsgengi barna (Laufey Dís Ragnarsdóttir o.fl., 2017). Niðurstöður erlendra rannsókna benda til pess að börn frá tekjulágum heimilum séu líklegri til að búa við verri heilsu en önnur börn, bæði í barnæsku og á fullorðinsárum (Elgar o.fl., 2015) og að upplifa kvíða (Pryor o.fl., 2019). Pá er vert að hafa í huga að börn einstæðra foreldra eru í verulega aukinni hættu á að búa við fátækt (Kolbeinn $\mathrm{H}$. Stefánsson, 2019). 
Kyn og kynvitund nemenda mótar einnig reynslu og sjálfsmynd peirra en ungmenni sem finnst pau tilheyra líffræðilegu kyni hafa sterkari sjálfsmynd og búa við traustari félagslega stöðu en ungmenni sem finnst pau tilheyra öðru kyni en líffræðilegt kyn peirra segir til um (Perry o.fl., 2019). Sama á við um íslensk ungmenni sem skilgreina sig kynsegin, en samkvæmt könnun Landlæknisembættisins eru pau ungmenni mun líklegri en jafnaldrar peirra til að tengjast skólasamfélaginu síður, og um helmingur peirra taldi sig eiga í slökum tengslum við vini (Ársæll Már Arnarsson o.fl., 2020).

Margir fleiri félagslegir pættir móta upplifun, líðan og stöðu barna og ungmenna og tengsl peirra við nærumhverfið. Rannsóknir sýna til að mynda að stuðningur foreldra og viðhorf peirra til skólastarfsins geta haft umtalsverð áhrif á upplifun nemenda og tengsl peirra við skólasamfélagið (Epstein, 2011). Íslensk rannsókn á námsgengi og skuldbindingu ungmenna sýnir að samband foreldra og ungmenna getur mótað fjölpætta skuldbindingu nemenda og samsömun peirra gagnvart skóla og námi (Kristjana Stella Blöndal og Sigrún Aðalbjarnardóttir, 2009, 2014). Pá eru vísbendingar um að samskipti við foreldra hafi sterkari tengsl við líðan ungmenna en tengsl við jafnaldra og styðji pannig við að ungmenni tengist nærumhverfi sínu vel (Ársæll Már Arnarsson o.fl., 2020; Uslu og Gizir, 2017).

Að sama skapi hefur góð og sterk sjálfsmynd jákvæð tengsl við félagslega stöðu ungmenna og pað hve mikið pau telji sig tilheyra skólasamfélaginu (Allen o.fl., 2017). Breyttir lífshættir ungmenna í samfélaginu, svo sem minni hreyfing, meiri skjátími og aukin notkun samfélagsmiðla, getur haft neikvæð áhrif á sjálfsmynd og líðan peirra. Yfirlitsrannsókn Allens o.fl. sýndi að meirihluti rannsókna á „,belonging" innan skóla bendi til pess að hæfni ungmenna til samskipta og tengslamyndunar hafi mikið að segja um hve slök eða sterk tengsl pau upplifi við samnemendur og kennara (Allen o.fl., 2017).

Rannsóknir hafa staðfest að áhættuhegðun ungmenna, svo sem regluleg áfengis- og fíkniefnaneysla, er einn af peim áhrifapáttum sem geta mótað upplifun peirra af að tilheyra. Fjölpjóðleg samanburðarrannsókn sýnir að íslensk ungmenni drekka minna, reykja minna og neyta síður vímuefna en ungmenni annarra Evrópulanda en að vaxandi munur er á áfengisneyslu peirra sem búa við slæman fjárhag og jafnaldra peirra (Ársæll Már Arnarsson og Póroddur Bjarnason, 2020). Pannig virðist forvarnarstarf undanfarinna áratuga síður ná til peirra sem standa höllum fæti fjárhagslega.

Nýleg íslensk rannsókn sýnir að almennt líður unglingum í 10. bekk vel í skólanum sínum og að meirihluti nemenda telur að kennarinn taki peim eins og peir eru (Ársæll Már Arnarsson o.fl., 2019). Engu að síður verður ekki horft fram hjá pví að fámennur en mikilvægur hópur ungmenna á erfitt uppdráttar innan íslenskra grunnskóla og finnur ekki til samsömunar við samnemendur og kennara. Markmið pessarar greinar er að varpa ljósi á hvernig kyn, uppruni og fjárhagsstaða móta upplifun grunnskólanemenda á Íslandi að tilheyra eða tilheyra ekki í skólaumhverfinu. Ennfremur að skoða hvort samskipti við foreldra, sjálfsmynd og áhættuhegðun skýri að einhverju leyti samband pessara priggja félagslegu pátta við upplifun nemenda af að tilheyra.

\section{Аðferð}

\section{Gögn}

Rannsókn pessi byggir á gögnum úr fjölpjóðlegu rannsókninni Heilsa og lifskjör skólabarna (Health Behaviour in School-Aged-Children, HBSC) sem er lögð fyrir í samstarfi við Alpjóðaheilbrigðisstofnunina (WHO). Rannsóknin hófst veturinn 2001-2002 og er lögð fyrir fjórða hvert ár í 50 löndum í Evrópu og Norður-Ameríku (HBSC, e.d.). Ísland hefur tekið pátt í henni frá 2006.

\section{Framkvæmd}

Gögnin sem hér er byggt á eru úr rafrænni fyrirlögn sem fór fram veturinn 2017-18. Gagnasöfnun HBSC nær til priggja árganga, nemenda í 6., 8. og 10. bekk. Óskað var eftir pví við skólastjóra allra 
skóla á Íslandi sem voru með börn í framangreindum árgöngum að nemendur peirra tækju pátt. Foreldrar og forráðamenn fengu send heim kynningarbréf og gátu óskað eftir pví að börn peirra tækju ekki pátt. Svör fengust frá 7.159 nemendum eða um 54\% af heildarfjölda pessara árganga. Nemendur svöruðu könnuninni í tölvu á skólatíma og fengu upplýsingar um að peim væri frjálst að sleppa pví að svara einstaka spurningum eða spurningalistanum í heild. Öll gögn voru ópersónugreinanleg og nöfn pátttakenda komu hvergi fram. Rannsóknaráætlun var send til Persónuverndar og til vísindasiðanefndar Háskóla Íslands og ekki voru gerðar athugasemdir við rannsóknina. Í pessari grein er unnið með afmarkaðar spurningar sem tengjast viðfangsefninu að tilheyra í skólanum.

\section{Mælitæki}

Gögnin voru greind með aðferð minnstu fervika (e. ordinary least squares). Svarbreyta pessarar rannsóknar er samsettur kvarði sem samanstendur af sex fullyrðingum sem pátttakendur í rannsókninni tóku afstöðu til og mæla mismunandi hliðar pess að upplifa að tilheyra í skóla:

1. Bekkjarfélögunum finnst gaman að vera saman.

2. Flestir bekkjarfélaganna eru vinsamlegir.

3. Bekkjarfélagarnir taka mér eins og ég er.

4. Kennararnir taka mér eins og ég er.

5. Mér finnst kennurunum vera annt um mig sem einstakling.

6. Ég treysti kennurunum mínum mjög vel.

Svarkostirnir voru fimm: 1) Mjög sammála, 2) Sammála, 3) Hvorki sammála né ósammála, 4) Ósammála, og 5) Mjög ósammála. Páttagreining benti til pess að saman endurspegluðu pessar mælingar einn undirliggjandi pátt með eigingildi 2,98, sem túlka má sem upplifun nemenda á hvort og hve mikið peir tilheyra í skólanum. Breyturnar voru sameinaðar í einn kvarða með pví að leggja pær saman. Gildi kvarðans spanna frá 1 til 25. Áreiðanleiki kvarðans verður að teljast mjög góður (Cronbach's alpha=0,848). Sams konar kvarði hefur áður verið notaður af Borraccino o.fl. (2020).

Skýringarbreyturnar í pessari rannsókn voru prjár; kyn, uppruni og fjárhagur fjölskyldunnar.

Kyn byggir á sjálfsskilgreiningum svarenda sem var boðið að skilgreina sig sem strák, stelpu eða annаð. Svarkostinum „,annað“ er ætlað аð fanga kynsegin einstaklinga, pað er einstaklinga sem skilgreina sig utan hefðbundinnar kynjatvíhyggju. Ætla má að hópurinn sem merkti við „annað“ sé nokkuð fjölbreyttur og er hugsanlegt að ekki allir einstaklingar sem völdu svarkostinn séu endilega kynsegin. Petta parf að hafa í huga við túlkun niðurstaðna, en pó er mikilvægt að birta upplýsingar um nemendur sem skilgreina sig ekki innan kynjatvíhyggju. Alls voru 3.530 drengir í gögnunum, 3.498 stúlkur og 118 einstaklingar sem völdu annað.

Uppruni var skilgreindur í prjá flokka út frá fæðingarlandi foreldra, pað er hvort báðir foreldrar hafi fæðst á Íslandi, annað foreldrið fæðst erlendis eða báðir foreldrar fæðst erlendis. Alls áttu 5.483 einstaklingar foreldra sem fæddust báðir á Íslandi, 998 áttu annað foreldri fætt erlendis og 318 áttu báða foreldra fædda erlendis.

Fjárhagur fjölskyldunnar byggði á mati barnanna sjálfra. Pátttakendur í rannsókninni voru spurðir „Hversu gott telur pú fjölskyldu pína hafa pað fjárhagslega?“ Svarkostirnir voru fimm, frá „Mjög gott“ yfir í „Mjög slæmt“. Par sem mjög fáir einstaklingar svöruðu „mjög slæmt“ felldum við saman svarkostina „slæmt“ og „mjög slæmt“. Ljóst er að petta er ekki sérlega nákvæm mæling á fjárhag fjölskyldna barna enda margt sem getur skekkt mat svarenda, eins og efnahagur annarra fjölskyldna í skólahverfinu og viðleitni tekjulágra foreldra til að hlífa börnum sínum við afleiðingum fátæktar (Jón Gunnar Bernburg o.fl., 2009; Main og Bradshaw, 2016). Engu að síður benda erlendar rannsóknir til pess að börn á fátækum heimilum hafi nokkuð skýra mynd af fjárhag fjölskyldunnar jafnvel pó foreldrar reyni að hlífa peim við afleiðingum fátæktarinnar og leggi sig jafnvel fram um að fela parfir sínar og langanir til að draga úr álagi á foreldra sína (Ridge, 2002, 2009, 2011). Pannig má 
ætla að prátt fyrir að mat barna á fjárhag fjölskyldu sinnar sé ekki hlutlæg mæling gefi hún ágæta vísbendingu um fjárhaginn.

\section{Tölfræði}

Tölfræðileg úrvinnsla var unnin með Stata til að greina lýsandi tölfræði. Pá voru gerðar fjórar aðhvarfsgreiningar til að varpa ljósi á tengsl skýringarbreyta og upplifun svarenda að tilheyra í skólanum. Í fyrstu greiningu voru eingöngu skýringarbreyturnar notaðar og í annarri greiningu var samvirkni milli peirra skoðuð. Auk pess að skoða samband breytanna við pá upplifun að tilheyra í skólaumhverfinu var samvirkni breytanna greind en ætla má að áhrif kyns, tekna og uppruna séu að nokkru leyti háð hvert öðru, pað er annaðhvort sterkari eða veikari fyrir suma hópa en aðra.

Í priðju, fjórðu og fimmtu greiningu var stýrt fyrir premur páttum í lífi svarenda sem tengjast svarbreytunni og í einhverjum tilfellum skýringarbreytunum, en petta voru tengsl við foreldra, áhattuhegðun og sjálfsmynd. Markmiðið var ekki að meta áhrif stýribreytanna sem slíkra heldur áhrifin sem pær hafa á samband skýringabreytanna og peirrar upplifunar að tilheyra í skólaumhverfinu og draga pannig fram hvaða öðrum áskorunum pau sambönd tengjast.

Í hverri greiningu var stýrt fyrir tilteknu atriði. Í peirri fyrstu var stýrt fyrir mati nemenda á hve góð eða slök tengsl peirra við foreldra eru. Mælingin hefur prjá svarkosti: 1) slök, 2) góð og 3) mjög góð. Við notum pá síðustu sem viðmiðunarhóp. İ annarri greiningunni er stýrt fyrir ýmiss konar áhættuhegðun, pað er hvort pátttakendur hafi einhvern tímann reykt, drukkið áfengi eða slegist. Allar pessar breytur eru tvíkosta og taka gildið 1 ef viðkomandi hefur einhvern tíma gert eitthvað af ofangreindu. Í sỉðustu greiningunni er stýrt fyrir sjálfsmynd viðkomandi. Sjálfsmynd er mæld með tveimur mælingum, pað er „Mér líkar vel við sjálfa(n) mig“ og „Ég er nógu góð(ur) eins og ég er“. Svarkostirnir við báðar spurningar eru á fimm punkta kvarða, frá 1) Mjög sammála og yfir í 5) Mjög ósammála. Við sameinuðum mælingarnar í eina níu punkta mælingu. Áreiðanleiki pessarar samsettu mælingar var mjög hár (Cronbach's alpha=0,915).

\section{Niðurstöður}

Alls svöruðu 7.159 nemendum og var svarhlutfall um 54\% af heildarpýði pessara árganga. Tafla 1 sýnir hvernig svarbreytan sem mælir upplifun á að tilheyra í skólaumhverfi er samsett og dreifingu svarenda samkvæmt henni. Stærstur hluti pátttakenda (44,5\%) er með gildi á bilinu 16 til 20, sem samsvarar svarkostinum „Sammála“ á hverri spurningu sem svarbreytan er samsett úr. Næst hæsta hlutfallið er með gildi á bilinu 21 til 25, eða 37,9\%, sem samsvarar „Mjög sammála“á hverri spurningu sem svarbreytan er samsett úr. Pað má pví segja að meirihluti svarenda, eða 82,4\% finnist pau tilheyra í skólaumhverfinu. 
Tafla 1. Dreifing samsettrar mælingar á að tilheyra í skóla og stökum mælingum hennar.

\begin{tabular}{|c|c|c|c|c|c|}
\hline & 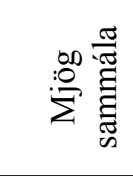 & 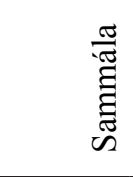 & 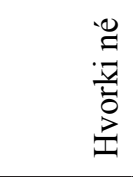 & 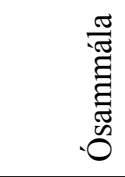 & 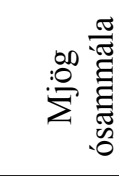 \\
\hline Bekkjarfélögum finnst gaman að vera saman & $27,1 \%$ & $47,3 \%$ & $19,0 \%$ & $4,5 \%$ & $2,1 \%$ \\
\hline Staðalvilla & 0,529 & 0,595 & 0,468 & 0,247 & 0,172 \\
\hline Flestir bekkjarfélaganna eru vingjarnlegir & $25,8 \%$ & $50,9 \%$ & $16,5 \%$ & $5,1 \%$ & $1,8 \%$ \\
\hline Staðalvilla & 0,528 & 0,598 & 0,444 & 0,263 & 0,157 \\
\hline Bekkjarfélagarnir taka mér eins og ég er & $33,5 \%$ & $44,4 \%$ & $14,8 \%$ & $4,9 \%$ & $2,4 \%$ \\
\hline Staðalvilla & 0,566 & 0,595 & 0,426 & 0,259 & 0,183 \\
\hline Kennararnir taka mér eins og ég er & $46,1 \%$ & $39,2 \%$ & $9,7 \%$ & $3,0 \%$ & $1,9 \%$ \\
\hline Staðalvilla & 0,595 & 0,582 & 0,354 & 0,205 & 0,161 \\
\hline Kennurunum er annt um mig sem einstakling & $28,7 \%$ & $41,8 \%$ & $20,7 \%$ & $6,3 \%$ & $2,5 \%$ \\
\hline Staðalvilla & 0,544 & 0,593 & 0,487 & 0,292 & 0,187 \\
\hline Ég treysti kennurunum mínum mjög vel & $34,3 \%$ & $36,7 \%$ & $18,2 \%$ & $7,4 \%$ & $3,4 \%$ \\
\hline Staðalvilla & 0,568 & 0,577 & 0,462 & 0,313 & 0,215 \\
\hline Gildi kvarða & $21-25$ & $16-20$ & $11-15$ & $6-10$ & $1-5$ \\
\hline Hlutföll & $37,9 \%$ & $44,5 \%$ & $13,6 \%$ & $2,9 \%$ & $1,1 \%$ \\
\hline Staðalvilla & 0,588 & 0,603 & 0,416 & 0,205 & 0,125 \\
\hline
\end{tabular}

Hvað varðar stakar fullyrðingar í Töflu 1, pá er mikill meirihluti nemenda sammála eða mjög sammála $(85,4 \%)$ pví að kennarar peirra taki peim eins og peir eru og pað sama á við ef aðeins er horft til peirra sem sögðust mjög sammála (46,1\%). Fullyrðingar sem lúta að upplifun á viðmóti kennara hafa hins vegar lægsta hlutfall peirra sem eru sammála eða mjög sammála og fullyrðingin „Ég treysti kennurunum mínum mjög vel“ mælist með hæsta hlutfall peirra sem eru ósammála eða mjög ósammála fullyrðingunni. Pó er vert að hafa í huga að 71\% nemenda er sammála eða mjög sammála pví að peir geti treyst kennaranum sínum mjög vel.

Hvað varðar pær mælingar sem lúta að upplifun á viðmóti samnemenda er dreifingin mjög svipuð til að mynda eru hlutföllin sem eru sammála eða mjög sammála fullyrðingunum á bilinu 74,4\% til $77,9 \%$ - en mælingin „Bekkjarfélagarnir taka mér eins og ég er“ sker sig pó að nokkru leyti úr par sem hærra hlutfall nemenda er „mjög sammála“ peirri fullyrðingu en hinum fullyrðingunum tveimur sem fanga upplifun á viðmóti nemenda.

Tafla 2 sýnir meðaltöl samsettu mælingarinnar á peirri upplifun að tilheyra í skólaumhverfinu fyrir mismunandi gildi skýringarbreytanna priggja. Munurinn á drengjum og stúlkum er hverfandi og langt frá pví að vera tölfræðilega marktækur. Aftur á móti virðist nemendum, sem svöruðu „annað“ um kyn sitt, ekki finnast peir tilheyra jafn vel í skólaumhverfinu og peir nemendur sem skilgreindu sig annaðhvort stúlku eða dreng. 
Tafla 2. Meðalgildi samsettrar mælingar á upplifun á að tilheyra í skóla eftir gildi á skýringarbreytum.

\begin{tabular}{|c|c|c|c|c|c|}
\hline & \multirow[b]{2}{*}{ Meðaltal } & \multirow[b]{2}{*}{ Staðalvilla } & \multicolumn{2}{|c|}{$\begin{array}{c}95 \% \\
\text { vikmörk }\end{array}$} & \multirow[b]{2}{*}{$\mathbf{n}$} \\
\hline & & & Neðri mörk & Efri mörk & \\
\hline Alls & 23,9 & 0,052 & 23,8 & 24,0 & 6803 \\
\hline \multicolumn{6}{|l|}{ Kyn } \\
\hline Drengir & 24,1 & 0,075 & 23,9 & 24,2 & 3296 \\
\hline Stúlkur & 23,9 & 0,070 & 23,8 & 24,1 & 3393 \\
\hline Annad & 19,4 & 0,619 & 18,1 & 20,6 & 106 \\
\hline \multicolumn{6}{|l|}{ Fjärhagur fjölskyldu } \\
\hline Mjög góður & 24,7 & 0,084 & 24,6 & 24,9 & 2744 \\
\hline Góður & 23,8 & 0,074 & 23,7 & 23,9 & 2692 \\
\hline Hvorki/né & 22,9 & 0,124 & 22,6 & 23,1 & 1118 \\
\hline Slæmur & 20,9 & 0,433 & 20,0 & 21,8 & 114 \\
\hline Mjög slæmur & 17,4 & 0,954 & 15,4 & 19,3 & 40 \\
\hline \multicolumn{6}{|l|}{ Erlendur bakgrunnur } \\
\hline Báđir foreldrar innfæddir & 24,1 & 0,056 & 24,0 & 24,2 & 5587 \\
\hline Annað foreldri erlent & 23,3 & 0,140 & 23,1 & 23,6 & 932 \\
\hline Báðir foreldrar erlendir & 22,4 & 0,341 & 21,8 & 23,1 & 284 \\
\hline
\end{tabular}

Skýrt samband er á milli mats barna á fjárhagsstöðu fjölskyldna peirra og peirrar upplifunar að tilheyra í skólanum. Meðalgildi kvarðans er hæst meðal peirra sem meta fjárhaginn mjög góðan og lægst hjá peim sem meta hann mjög slæman. Munurinn á milli punkta á fjárhagsmælingunni er í öllum tilfellum tölfræðilega marktækur. Рað pýðir að við höfum mikla vissu fyrir að börn sem meta fjárhag heimila sinna sem mjög góðan upplifa sterkar að pau tilheyri í skólanum en börn sem meta fjárhag heimila sinna sem góðan, sem aftur upplifa sterkar að tilheyra en börn sem meta fjárhag heimila sinna hvorki góðan né slæman og svo koll af kolli. Almennt er munurinn á milli tekjuhópa nokkuð svipaður, um eitt stig á 25 punkta kvarða. Börn sem meta fjárhag heimila sinna sem mjög slæman skera sig pó úr, munurinn á peim og næsta tekjuhópi fyrir ofan pau er 3,5 stig, sem bendir til pess að pað sé eitthvað í aðstæðum pessara nemenda sem veldur pví að pau upplifa mun síður en aðrir að tilheyra í skólanum.

Nemendum sem eiga annað eða bæði foreldri erlent virðist síður finnast peir tilheyra í skólanum en nemendum hverra foreldrar eru hvorugt með erlendan bakgrunn. Raunar virðist nemendum sem eiga báða foreldra af erlendum uppruna sỉður finnast peir tilheyra en peim sem áttu aðeins annað foreldri af erlendum uppruna en munurinn á mælingu hópanna var pó ekki tölfræðilega marktækur. Við getum pó sagt með vissu að nemendur með erlendan bakgrunn virðast upplifa síður að peir tilheyri í skólaumhverfinu en nemendur sem ekki hafa erlendan bakgrunn.

Pað er samband á milli ofangreindra greiningarbreyta pannig að hluti af „áhrifum“ peirra inniheldur áhrif frá hinum breytunum. Sem dæmi má nefna að börn sem eiga báða foreldra erlenda eru öðrum líklegri til að búa við bágan fjárhag. Hluti af sambandinu á milli fjárhags og samsömunar inniheldur pannig áhrif uppruna og hluti af sambandinu á milli uppruna og samsömunar inniheldur áhrif mismunandi fjárhagsstöðu peirra. Tafla 3 sýnir niðurstöður úr aðhvarfsgreiningum 1 og 2. 
Tafla 3. Stuðlar úr aðhvarfsgreiningum (OLS). Kyn, erlendur bakgrunnur og fjárhagur fjölskyldu, með og án samvirkniáhrifa.

\begin{tabular}{|c|c|c|}
\hline & Greining 1 & Greining 2 \\
\hline \multicolumn{3}{|l|}{ Kyn } \\
\hline Drengir & - & - \\
\hline Stúlkur & $-0,17(0,10)$ & $0,03(0,17)$ \\
\hline Annað & $-3,44(0,44)^{* *}$ & $-4,25(0,90)^{* *}$ \\
\hline \multicolumn{3}{|l|}{ Erlendur bakgrunnur } \\
\hline Báđir foreldrar íslenskir & - & - \\
\hline Annað foreldri erlent & $-0,62(0,15)^{* *}$ & $-0,74(0,31)^{*}$ \\
\hline Báðir foreldrar erlendir & $-1,04(0,27)^{* *}$ & $-0,23(0,54)$ \\
\hline \multicolumn{3}{|l|}{ Fjárhagur fjölskyldu } \\
\hline Mjög góður & - & - \\
\hline Góður & $-0,94(0,12)^{* *}$ & $-0,96(0,17)^{* *}$ \\
\hline Hvorki né & $-1,82(0,15)^{* *}$ & $-1,74(0,22)^{* *}$ \\
\hline Slæmur & $-4,29(0,35)^{* *}$ & $-4,38(0,59)^{* *}$ \\
\hline \multicolumn{3}{|l|}{ Samvirkni: Kyn*erlendur bakgrunnur } \\
\hline Stúlkur*annað foreldri fætt erlendis & & $-0,40(0,31)$ \\
\hline Stúlkur*báðir foreldrar fæddir erlendis & & $-1,26(0,56)^{*}$ \\
\hline Annað*annað foreldri fætt erlendis & & $2,55(1,17)^{*}$ \\
\hline Annað*báðir foreldrar fæddir erlendis & & $-2,91(1,32)^{*}$ \\
\hline \multicolumn{3}{|l|}{ Samvirkni: Kyn*fjárhagur fjölskyldu } \\
\hline Stúlkur*góður & & $-0,12(0,23)$ \\
\hline Stúlkur*hvorki né & & $-0,28(0,30)$ \\
\hline Stúlkur*slæmur & & $0,259(0,73)$ \\
\hline Annað*góður & & $1,73(1,13)$ \\
\hline Annað*hvorki né & & $0,13(1,19)$ \\
\hline Annað*slæmur & & $4,89(1,83)^{*}$ \\
\hline \multicolumn{3}{|c|}{ Samvirkni: Erlendur bakgrunnur*fjárhagur fjölskyldu } \\
\hline Annað foreldri erlent*góður & & $0,34(0,35)$ \\
\hline Annað foreldri erlent*hvorki/né & & $0,46(0,43)$ \\
\hline Annað foreldri erlent*slæmur & & $0,98(0,90)$ \\
\hline Báðir foreldrar erlendir*góður & & $0,42(0,63)$ \\
\hline Báðir foreldrar erlendir*hvorki/né & & $0,14(0,75)$ \\
\hline Báðir foreldrar erlendir*slæmur & & $-3,54(1,47)^{*}$ \\
\hline Fasti & $20,1(0,10)^{* *}$ & $20,0(0,12)^{* *}$ \\
\hline $\mathrm{N}$ & 6260 & 6261 \\
\hline DF & 7 & 23 \\
\hline R2 & 0,062 & 0,68 \\
\hline
\end{tabular}

$* \mathrm{P}<0,05 ; * * \mathrm{P}<0,001$ 
Tafla 3 sýnir niðurstöður úr tveimur aðhvarfsgreiningum. Sú fyrri (greining 1) sýnir niðurstöðuna pegar við notum einungis skýringarbreyturnar í greininguna. Drengir eru viðmiðunarhópurinn fyrir kyn og stuðlarnir sýna pannig áhrifin af að vera stúlka eða „,annað“ í samanburði við að vera karlkyns. Munurinn á milli drengja og stúlkna hvað varðar að finnast pau tilheyra í skólaumhverfinu er lítill og ekki tölfræðilega marktækur. Aftur á móti finnst peim sem völdu „annað“ pau síður tilheyra en drengir og stúlkur. Munurinn er 3,44 stig á 25 punkta kvarðanum sem mælir upplifun á að tilheyra í skólaumhverfinu. Pannig getum við tekið dæmi um dreng, sem á báða foreldra íslenska og býr við góðan fjárhag, pá spáir líkanið að viðkomandi hafi gildið 19,2 á samsettu mælingunni en 15,7 ef viðkomandi skilgreinir sig hvorki sem karlkyns né kvenkyns.

Hvað varðar erlendan bakgrunn pá er sambandið skýrt. Nemendum sem eiga annað foreldri fætt erlendis finnst peir tilheyra síður en peir sem eiga báða foreldra íslenska og peir sem eiga báða foreldra erlenda upplifa sig enn síður tilheyra í skólanum.

Greining 1 sýnir einnig samband á milli fjárhags heimilisins og pess að finnast maður tilheyra í skólaumhverfinu. Pau sem telja fjárhag fjölskyldu sinnar mjög slæman skera sig pó úr hvað varðar stærð áhrifa. Munurinn á peim sem búa við góðan og mjög góðan fjárhag er um 0,9 stig á 25 punkta svarbreytunni, sem og munurinn á peim sem búa við góðan fjárhag og peim sem telja fjárhag fjölskyldna sinna hvorki góðan né slæman. Munurinn á milli peirra sem meta fjárhag fjölskyldna sinna hvorki góðan né slæman og peim sem meta hann slæman er hins vegar 2,5 stig. Pannig standa upp úr tveir pættir sem hafa mikil áhrif á pað hvort nemendur upplifi að peir tilheyri í skólanum, pað er að skilgreina kyn sitt hvorki sem karlkyns né kvenkyns og að meta fjárhag fjölskyldu sinnar sem slæman.

Greining 2 sýnir samvirkniáhrif milli breyta og sýna niðurstöður að samvirkni kyns og erlends bakgrunns er umtalsverð. Pannig hefur pað takmörkuð áhrif á upplifun drengja sem eiga báða foreldra fædda erlendis að tilheyra í skólanum, pað dregur nokkuð úr peirri upplifun hjá stúlkum og enn meira hjá peim sem skilgreina sig hvorki sem karlkyns né kvenkyns. Líkanið spáir pví að drengur og stúlka sem búa við góðan fjárhag og eiga báða foreldra íslenska hafi gildið 19 á 25 punkta kvarðanum sem mælir pá upplifun að tilheyra í skólaumhverfinu. Líkanið spáir pví að drengur sem á báða foreldra erlenda og býr við góðan fjárhag hafi gildið 19,2. Ef stúlkurnar eiga hins vegar báða foreldra erlenda en búa við góðan fjárhag spáir líkanið peim gildinu 13,9. Fyrir einstaklinga sem skilgreina sig hvorki sem karlkyns né kvenkyns, eiga báða foreldra íslenska og búa við góðan fjárhag spáir líkanið gildinu 13,8. Greiningin sýnir pví að drengir og stúlkur sem eiga foreldra af erlendum uppruna og einstaklingar sem skilgreina sig sem hvorki drengi né stúlkur séu líklegri til að upplifa síður að pau tilheyri í skólaumhverfinu.

Almennt eru engin tölfræðilega marktæk samvirkniáhrif á milli pess að eiga annað foreldri fætt erlendis annars vegar og kyns eða fjárhags hins vegar. Á pessu er ein undantekning, pað er á milli pess að skilgreina sig hvorki sem karlkyns né kvenkyns og að eiga annað foreldri fætt erlendis. Par eru áhrifin ekki aðeins tölfræðilega marktæk heldur einnig jákvæð. Рað pýðir pó ekki að pessi hópur búi við sterkari tilfinningu en aðrir um að tilheyra í skólaumhverfinu. Áhrifin af að tilheyra hópnum sem skilgreindi sig hvorki sem drengi né stúlkur eru eftir sem áður neikvæð og mun meiri. Petta pýðir í raun að pau áhrif eru einfaldlega veikari fyrir pennan hóp en að pau séu eftir sem áður neikvæð. Pannig spáir líkanið til dæmis einstaklingi sem skilgreinir sig hvorki sem karlkyns né kvenkyns, sem á annað foreldrið fætt erlendis og býr við fjárhag sem er hvorki góður né slæmur, gildinu 16,4 á svarbreytunni en spáir gildinu 18 ef viðkomandi skilgreinir sig sem karlkyns, en 14,9 ef viðkomandi ætti báða foreldra fædda á Íslandi en skilgreindi sig hvorki sem dreng né stúlku og fjárhagurinn væri sá sami.

Samvirknin á milli pess að skilgreina sig hvorki sem karlkyns né kvenkyns og bágs fjárhags er einnig tölfræðilega marktæk og jákvæð nema áhrifin eru mun sterkari en fyrir að eiga annað foreldri fætt erlendis. Рað pýðir að neikvæð áhrif á pá upplifun að tilheyra í skólasamfélaginu sem leiða af að skilgreina sig hvorki sem karlkyns né kvenkyns eru til staðar óháð fjárhag nema hjá peim sem búa við slæman fjárhag. Saman eru pó áhrifin af slæmum fjárhag og pví að skilgreina sig hvorki sem dreng né stúlku mun meiri en áhrifin af samvirkninni. 
Að lokum er samvirknin á milli pess að eiga báða foreldra fædda erlendis og að fjölskyldan búi við slæman fjárhag umtalsvert neikvæð og tölfræðilega marktæk. Pannig spáir líkanið til dæmis drengjum sem eiga báða foreldra fædda á Íslandi og búa við slæman fjárhag gildinu 15,6 á svarbreytunni en 11,9 ef báðir foreldrar eru fæddir erlendis.

Tafla 4. Stuðlar úr aðhvarfsgreiningum (OLS). Stýrt fyrir samskiptum við foreldra, áhættuhegðun og sjálfsmynd.

\begin{tabular}{|c|c|c|c|c|}
\hline & Greining 1 & Greining 1 & Greining 4 & Greining 5 \\
\hline & & Samskipti við foreldra & Áhættuhegðun & Sjálfsmynd \\
\hline \multicolumn{5}{|l|}{ Kyn } \\
\hline Drengir & - & - & - & - \\
\hline Stúlkur & $-0,17(0,10)$ & $0,00(0,10)$ & $-0,56(0,11)^{* *}$ & $0,36(0,10)^{* *}$ \\
\hline Annad & $-3,44(0,44)^{* *}$ & $-3,17(0,43)^{* *}$ & $-2,80(0,43)^{* *}$ & $-2,56(0,40)^{* *}$ \\
\hline \multicolumn{5}{|l|}{ Erlendur bakgrunnur } \\
\hline Báðir foreldrar íslenskir & - & - & - & - \\
\hline Annað foreldri erlent & $-0,62(0,15)^{* *}$ & $-0,45(0,15)^{*}$ & $-0,45(0,15)^{*}$ & $-0,49(0,14)^{* *}$ \\
\hline Báđir foreldrar erlendir & $-1,04(0,27)^{* *}$ & $-0,80(0,26)^{*}$ & $-0,56(0,27)^{*}$ & $-0,59(0,25)^{*}$ \\
\hline \multicolumn{5}{|l|}{ Fjárhagur fjölskyldu } \\
\hline Mjög góður & - & - & - & - \\
\hline Góður & $-0,94(0,12)^{* *}$ & $-0,54(0,11)^{* *}$ & $-0,87(0,11)^{* *}$ & $-0,34(0,11)^{*}$ \\
\hline Hvorki né & $-1,82(0,15)^{* *}$ & $-1,07(0,15)^{* *}$ & $-1,58(0,15)^{* *}$ & $-0,61(0,14)^{* *}$ \\
\hline Slæmur & $-4,29(0,35)^{* *}$ & $-3,00(0,35)^{* *}$ & $-3,34(0,35)^{* *}$ & $-2,18(0,33)^{* *}$ \\
\hline \multicolumn{5}{|l|}{ Tengsl við foreldra } \\
\hline Slök & & $-2,70(0,14)^{* *}$ & & \\
\hline Góð & & $-1,38(0,12)^{* *}$ & & \\
\hline Mjög góð & - & - & - & - \\
\hline \multicolumn{5}{|l|}{ Áhættuhegðun } \\
\hline Hefur reykt & & & $-1,17(0,24)^{* *}$ & \\
\hline Hefur drukkið áfengi & & & $-1,09(0,16)^{* *}$ & \\
\hline Hefur slegist & & & $-1,42(0,12)^{* *}$ & \\
\hline \multicolumn{5}{|l|}{ Sjálfsmynd } \\
\hline Sjálfsmynd & & & & $0,93(0,03)^{* *}$ \\
\hline Fasti & $20,1(0,10)^{* *}$ & $20,4(0,10)^{* *}$ & $20,7(0,11)^{* *}$ & $12,58(0,22)^{* *}$ \\
\hline $\mathrm{N}$ & 6260 & 6260 & 6260 & 6260 \\
\hline DF & 7 & 9 & 10 & 8 \\
\hline $\mathrm{R} 2$ & 0,062 & 0,116 & 0,107 & 0,225 \\
\hline $\begin{array}{l}\text { Staðalvillur innan sviga } \\
\text { stuðla }\end{array}$ & & & & \\
\hline
\end{tabular}

sýnir niðurstöður úr fjórum aðhvarfsgreiningum, greiningu 1 má sjá til samanburðar. Í hinum premur stýrum við fyrir premur páttum sem tengjast peirri upplifun að tilheyra í skóla annars vegar og skýringarbreytunum premur hins vegar, pað er samskiptum við foreldra, áhættuhegðun og sjálfsmynd. Markmiðið er að greina áhrif á samband skýringarbreyta við pá upplifun að tilheyra innan skólaumhverfisins. 
Hvað varðar fjárhag pá hefur sjálfsmynd hvað sterkust áhrif á samband fjárhags og peirrar upplifunar að tilheyra í skólaumhverfinu. Sambandið veikist umtalsvert, nær helmingast fyrir pann hóp sem metur fjárhag fjölskyldu sinnar slæman og veikist hlutfallslega meira en pað fyrir pau sem mátu fjárhag fjölskyldna sinna sem góðan eða hvorki góðan né slæman. Tengsl við foreldra veikja sambandið á milli svar- og skýringabreyta líka umtalsvert en áhættuhegðun hefur fyrst og fremst áhrif á sambandið á milli pess að búa við slæman fjárhag og upplifun á að tilheyra í skóla. Fjárhagur fjölskyldu hefur eftir sem áður áhrif óháð pessum páttum.

Pegar kemur að peim sem áttu annað foreldrið fætt erlendis breytir litlu að stýra fyrir sambandi við foreldra, áhættuhegðun eða sjálfsmynd. Fyrir pau sem eiga báða foreldra fædda erlendis hafa pessir pættir allir umtalsverð áhrif en pó einkum áhættuhegðun og sjálfsmynd.

Myndin er ögn flóknari pegar kemur að kyni. Fyrir pau sem skilgreina sig hvorki sem karlkyns né kvenkyns dregur mest úr sambandinu við að tilheyra í skóla ef við stýrum fyrir sjálfsmynd og par á eftir kemur áhættuhegðun. Рað hefur hins vegar fremur hófleg áhrif að stýra fyrir tengslum við foreldra.

Hvað varðar stúlkur pá breytir litlu að stýra fyrir tengslum við foreldra en munurinn á drengjum og stúlkum verður hins vegar tölfræðilega marktækur pegar stýrt er fyrir áhættuhegðun og sjálfsmynd. Pá kemur í ljós ákveðinn kynjamunur par sem áhættuhegðun hefur mun meiri áhrif hjá drengjum en sjálfsmynd hefur meiri áhrif hjá stúlkum. Pegar við stýrum fyrir áhættuhegðun eru áhrifin af að vera stúlka neikvæð í samanburði við að vera drengur en hið gagnstæða á við um sjálfsmynd. Pví túlkum við niðurstöðuna pannig að aukin áhættuhegðun dragi úr peirri tilfinningu drengja að tilheyra í skólaumhverfinu á meðan neikvæð sjálfsmynd hefur sömu áhrif á stúlkur.

\section{Umræða}

Markmið pessarar greinar er að varpa ljósi á hvernig kyn nemenda, fjárhagsstaða og erlendur uppruni móta upplifun peirra af að tilheyra eða tilheyra ekki í skólaumhverfinu. Pá var markmið rannsóknar einnig að skoða hvaða áhrif samskipti við foreldra, áhættuhegðun og sjálfsmynd nemenda hefðu á ofangreint samband.

Niðurstöður sýna að almennt séð upplifa nemendur í íslenskum grunnskólum að peir tilheyri í skólaumhverfinu og raunar aðeins lítill hópur, eða um 4\%, sem upplifir pað að tilheyra ekki. Upplifun nemenda af að tilheyra var mæld á 25 punkta svarkvarða og var meðaltal svarenda 23,9. Slæm fjárhagsstaða nemenda hafði mest neikvæð tengsl við tilfinningu peirra af að tilheyra (meðaltal 17,4), pví næst komu nemendur sem skilgreina sig utan hefðbundinnar kynjatvíhyggju eða sem „annað“ (meðaltal 19,4), og að lokum sýndu gögnin að nemendur af erlendum uppruna eru líklegri en jafnaldrar til að samsama sig síður skólasamfélaginu (meðaltal 22,4). Pá sýndu niðurstöður að samskipti við foreldra, áhættuhegðun og sjálfsmynd höfðu töluverð tengsl við ofangreind sambönd.

Pessar niðurstöður eru ápekkar fyrri niðurstöðum, bæði innlendum og erlendum sem benda til að ýmsir samverkandi pættir hafi áhrif á virka pátttöku nemenda og pað hvernig peir upplifa stöðu sína í skólasamfélaginu (Ârsæll Már Arnarsson o.fl., 2019; Korpershoek o.fl., 2020). Rannsóknir sem snúa að félagslegri samsömun og tengslum nemenda við samnemendur sína og kennara hafa sýnt niðurstöður sem halla - bæði námslega og félagslega - á pann hóp sem hér virðist helst eiga undir högg að sækja (sjá t.d. OECD, 2019). Pað kom rannsakendum pó að einhverju leyti á óvart að niðurstöður sýndu óverulegan mun á upplifun drengja og stúlkna af að tilheyra innan skólasamfélagsins, par sem ýmsar rannsóknir sýna fram á kynjamun pegar kemur að líðan, velferð og félagslegum tengslum (Áslaug Pálsdóttir o.fl., 2012; Margrét Lilja Guðmundsdóttir o.fl., 2016) Vissulega má greina ákveðinn kynjamun pegar tiltekin tengsl eru skoðuð, til að mynda pá hefur sjálfsmynd stúlkna meiri áhrif á upplifun peirra af að tilheyra innan skólans en á meðal drengja hefur áhættuhegðun meiri tengsl en sjálfsmynd peirra við lakari samsömun innan skóla. Munur á milli drengja og stúlkna jafnast pó verulega út pegar að litið er til niðurstaðna í heild. Á hinn bóginn er mun líklegra að pau sem upplifa 
sig ekki innan kynjatvíhyggju eigi félagslega erfitt uppdráttar innan skólans og samsami sig síður við samnemendur. Ungt kynsegin fólk stendur að ýmsu leyti höllum fæti, er líklegra en jafningjarnir til að hafa neikvæða sjálfsmynd og finna til vanlíðunar vegna prýstings frá jafningjahópi um kynvitund sína (Perry o.fl., 2019). Í ljósi íslenskra niðurstaðna frá Landlæknisembættinu (Ársæll Már Arnarsson o.fl., 2020) um kynsegin ungmenni sem eru líklegri en önnur ungmenni til að vera í slökum tengslum við vini sína eru pessar niðurstöður eindregin áminning um að gripið verði til aðgerða til að bæta stöðu pessa hóps ungmenna.

Niðurstöður sýna, líkt og fyrri rannsóknir, að greina má aukinn mun á stöðu og velferð ungmenna eftir félags- og efnahagsstöðu peirra (Ársæll Már Arnarsson og Póroddur Bjarnason, 2020; Kolbeinn H. Stefánsson, 2019; OECD, 2019). Skýrt samband reyndist vera á milli fjárhagsstöðu og upplifunar nemenda á að tilheyra. Pó að eingöngu 2,6\% nemenda hafi metið fjárhag fjölskyldunnar sem slæman eða mjög slæman pá ber að hafa í huga að pessi rannsókn sýnir, líkt og fyrri rannsóknir, að peir nemendur sem tilheyra ýmsum öðrum jaðarhópum, eru til dæmis af erlendum uppruna, búa hjá einstæðu foreldri, eða upplifa sállíkamlega vanlíðan og heilsuleysi, búa oftar við fátækt en önnur börn (Ársæll Már Arnarsson o.fl., 2019; Kolbeinn H. Stefánsson, 2019; Pryor o.fl., 2019). Peirra félagslegu áskoranir geta pví verið víðtækar og kalla á sértæk viðbrögð skólasamfélagins, ekki síst til að sporna við neikvæðum afleiðingum sem geta fylgt pessum einstaklingum inn í fullorðinsárin (Elgar o.fl., 2015).

Nemendur sem hafa erlendan bakgrunn skera sig verulega úr pegar litið er til hve vel peir upplifa sig tilheyra innan skólasamfélagsins, og pá sérstaklega nemendur sem eiga báða foreldra erlenda. Hugsanlega er hér vísbending um pað sem Korpershoek o.fl. (2020) benda á, að sú tilfinning að tilheyra tengist pví hvernig nemendur upplifa að peir séu persónulega sampykktir, virtir og studdir af öðrum úr hinu félagslega umhverfi skólans. Fyrri rannsóknir á stöðu ungmenna af erlendum uppruna í íslensku skólasamfélagi benda eindregið til pess að pau upplifi ýmsar félagslegar og menningarlegar hindranir sem hamli fullri aðild peirra að samfélagi jafningja (Hanna Ragnarsdóttir og Fríða B. Jónsdóttir, 2016; Hermína Gunnpórsdóttir og Lilja Rós Aradóttir, 2021). Pessi rannsókn sýnir fram á, líkt og Borraccino o.fl. (2020), að pað skipti ungmenni af erlendum uppruna miklu að unnið sé markvisst að pví að efla félagslegt tengslanet peirra við jafnaldra og skólasamfélagið í heild. Sé pað ekki gert skapast aðstæður fyrir einangrun og aðskilnað frá samfélaginu með tilheyrandi neikvæðum afleiðingum fyrir einstaklingana og samfélagið (Hermína Gunnpórsdóttir og Lilja Rós Aradóttir, 2021).

Rannsóknin sýndi að samskipti við foreldra, sjálfsmynd og áhættuhegðun skýrðu að einhverju leyti sambandið á milli bakgrunnspátta og pess að finnast maður tilheyra í skólaumhverfinu en sjaldnast pó allir prír pættirnir saman. Raunar var pað aðeins á meðal nemenda sem áttu báða foreldra af erlendum uppruna að allir prír pættir skýrðu sambandið við áðurnefnda upplifun. Samskipti við foreldra skýrðu minnst af samböndum á milli skýringarbreyta og pess að upplifa að tilheyra í skólaumhverfinu en hafði pó veruleg áhrif á stöðu peirra nemenda sem áttu báða foreldra með erlendan bakgrunn og nokkur áhrif á stöðu peirra sem skilgreindu sig sem kynsegin eða „annað“.

Ein meginniðurstaða pessarar rannsóknar er að pað er samspil á milli ólíkra félagslegra og persónubundinna pátta sem hefur áhrif á hvernig ungmenni upplifa sig sem pátttakendur innan skólasamfélagsins, hvort pau telji sig tilheyra pví samfélagi. Ef fallist er á pá kenningu að virkni og áhugi nemenda sé forsenda náms, pá er ástæða til að hafa áhyggjur af peim hópi nemenda sem einhverra hluta vegna er jaðarsettur og tengist hvorki samnemendum né kennurum vel. Rannsóknin staðfestir að félags- og efnahagsstaða grunnskólanema hefur veruleg áhrif á samsömun og jaðarsetningu peirra, sem endurspeglar hinn félagslega ójöfnuð sem finna má í íslensku samfélagi, líkt og í öðrum samfélögum hins vestræna heims.

\section{Hagnýtur lærdómur}

Í ljósi pess að upplifun á að tilheyra eða tilheyra ekki í skólaumhverfinu getur haft ýmsar afleiðingar pá má færa rök fyrir að niðurstöðurnar veiti tilefni til inngrips og úrræða. Mikilvægt er að kennarar og annað fagfólk í skóla- og frístundastarfi hugi sérstaklega að börnum sem búa við aðstæður sem 
falla undir einhverja af ofangreindum páttum. Verkefni skólasamfélagsins er af peim sökum að vinna markvisst að pví að hver nemandi fái pau skilaboð að hann skipti aðra máli og að honum sé tekið á eigin forsendum. Kennarar gegna lykilhlutverki við að efla alhliða proska nemenda, skapa félagslegt öryggi og jákvæða skólamenningu. Pví er nauðsynlegt að auka áherslur íkennaramenntun á aðferðir til að efla samskiptahæfni, styrkja vináttutengsl og uppbyggjandi samfélag innan bekkja og námsheilda. Рað er von höfunda að niðurstöður pessarar rannsóknar nýtist kennurum, kennaranemum og öðru fagfólki sem starfar með börnum og ungmennum í skóla- og frístundastarfi.

Niðurstöðurnar benda til pess að úrræði til að styrkja aðild allra nemenda að skólasamfélaginu ættu að beinast sérstaklega að jaðarhópum, s.s. kynsegin ungmennum, peim sem búa við bágan fjárhag og börnum með erlendan bakgrunn. Niðurstöðurnar benda hins vegar einnig til pess að pað purfi að einhverju leyti ólík úrræði fyrir mismunandi hópa. Sem dæmi má nefna að úrræði fyrir nemendur sem búa við bágan fjárhag gætu snúist um að styrkja sambandið við foreldra og bæta sjálfsmynd nemenda en рað væri markvissara að úrræði sem beindust að drengjum snerust um að styrkja samband peirra við foreldra og að draga úr áhættuhegðun. Pá kann að vera að áhrifaríkasta inngripið í líf jaðarsettra nemenda sem ekki upplifa að tilheyra skólasamfélaginu sé að nýta aðferðir óformlegs náms og virkja fagfólk á vettvangi frístunda, s.s. tómstunda- og félagsmálafræðinga, innan skólans til að vinna markvisst með samskipti, félagstengsl, hópefli og virka pátttöku allra. Pannig má auka möguleika pessara nemenda á að taka pátt í samfélagi jafnaldra sinna á meiri jafningjagrundvelli sem getur haft jákvæð áhrif á sjálfsmynd peirra.

Pessi grein segir ekki til um hvaða úrræði gætu nýst mismunandi hópum. Рað er pví ljóst að frekari rannsókna er pörf en pessi grein gefur hins vegar vísbendingar um hvar sé best að byrja að leita að lausnum.

\section{Styrkleikar og veikleikar rannsóknar}

Hátt svarhlutfall í rannsókninni rennir styrkum stoðum undir að niðurstöður endurspegli ágætlega upplifun íslenskra grunnskólanema á að tilheyra innan skólans. Pað er rétt að árétta að niðurstöður pessarar rannsóknar byggja á upplifun og mati nemenda og ekki var aflað gagna um viðhorf kennara eða annars starfsfólks skóla. Greinin varpar ljósi á að tiltekinn hópur grunnskólanemenda er í áhættu á jaðarsetningu innan skólasamfélagsins. Nánar parf að greina hvaða leiðir eru færar fyrir kennara og annað fagfólk til að stuðla að virkri pátttöku allra innan skólasamfélagsins.

Margir samverkandi pættir hafa áhrif á félagslegan veruleika og upplifun einstaklinga. Pessi rannsókn beindist einkum að pví að skoða hvernig kyn nemenda, uppruni peirra og fjárhagsstaða mótaði samsömun peirra við skólasamfélagið. Ekki var horft til fötlunar sem vitað er að getur hindrað pátttöku og aðgengi nemenda að skólasamfélaginu. Pví er frekari rannsókna pörf til að skoða stöðu fatlaðra grunnskólanema sem og annarra jaðarhópa sem hér er ekki fjallað um.

\section{Belonging in the school: Factors affecting the perception of primary school stu- dents}

Educational policy in Iceland emphasizes the importance of supporting and respecting student diversity and wellbeing. The aim of this article is to shed light on how social factors such as students' gender, immigrant background and financial status shape their experience of belonging or not belonging to the school community. Previous research on "belonging" indicates that students who have a strong feeling that they belong to the school community generally do better academically and have a stronger position than those who feel marginalized, for example in terms of interest in school, self-image, classroom behaviour and academic achievement but a negative experience is associated with, for example, school drop-out (Christenson and Reschly, 2010; Korpershoek et al., 2020; OECD, 2019). Those students who are less likely to experience belonging are at greater 
risk of being exposed to negative social influences, and are more likely to have low self-esteem, and suffer from anxiety and depression (Allen et al., 2018; Gillen-O'Neel and Fuligni, 2013).

The aim of this article is to explore how gender, risk behaviour and financial status may connect to either belonging or not belonging to the school environment in the Icelandic context. The research questions are:

How does gender, immigrant background and financial status affect students' perception of belonging within the school environment?

To which extent do relationships with parents, self-image and risk behaviour mediate the connection between the different background factors (gender, background and financial status) to students' perception of belonging within the school environment?

This research is linked to Health Behaviour in School-Aged Children, a cross-national study carried out in collaboration with the World Health Organisation. The study was launched in 1983 and is conducted every four years. Iceland has participated since 2006.

The data used here is from an electronic survey carried out during the winter 2017-2018. The HBSC data collection covers three age cohorts; that is, children in years 6, 8 and 10. The headmasters of all compulsory schools in Iceland with children in the age groups indicated above were asked to facilitate the participation of their students. A total of 7,159 students participated in the study, yielding a 54\% response rate. 3,540 boys participated, 3,498 girls and 118 students identified as nonbinary or "other". This article analyses selected questions relating to the topic "to belong" in the school. A response scale to measure school belonging was developed from six items in the study, including the following: Other students accept me as I am, The teachers accept me as I am. The three main variables explored were gender, immigrant background, and financial status. Nevertheless, as the literature suggests, a number of social factors may explain school belonging; furthermore, this study analysed the mediating effects of communication with parents, risk behaviour and self-image on the identified relationships to school belonging.

The findings of this study show that students generally feel that they belong in the school environment and it is only a small group, approximately $4 \%$, who perceive themselves as not belonging. Students who identified the financial status of their family as poor and students who identified nonbinary or "other" were more likely than their peers to experience less belonging to the school community. The overall findings do not show a significant difference between boys and girls. Poor financial status had the greatest mediating effect on how gender relates to students' belonging in the school community, as boys were less affected by a poor financial situation. Risk behaviour was much more strongly associated with boys' sense of belonging rather than that of girls, but girls' poor self-esteem was more closely linked to their experience of not belonging. There was a strong synergy between having both parents born abroad and poor financial status. A strong self-image had a positive effect on the identification of students living in poor financial conditions.

One of the main conclusions of this research is that there is a complex interaction between social factors and young people's self-assessment which influences how they see themselves as participants in the school community and whether they feel they belong in that community. There are grounds for being concerned about the group of students who have been marginalised, for one reason or another, and who do not feel that they belong within the peer community. The analysis shows that students' social and economic situation significantly impacts their relationships with peers and teachers within the school, reflecting the social discrimination found in Iceland, as in other societies in the Western world. 
The results indicate that action is needed to ensure everyone's access to the school community and specific attention should be paid to marginalized students. It is the responsibility of the school community to work untiringly at conveying the message to all students that they matter and that they are accepted on their own terms. Teachers have a key role in supporting students and creating a safe and positive school culture. The authors hope the results of this research will encourage teachers and other professionals who work with children to address issues requiring support for those who are less socially integrated.

Key words: belonging, primary students' experiences, school environment, social inclusion

\section{Um höfunda}

Kolbrún P. Pálsdóttir (kolbrunp@hi.is) er dósent og forseti Menntavísindasviðs Háskóla Íslands. Hún lauk BA-prófi í heimspeki 1997, MA-gráðu í menntunarfræðum 2001 og PhD-gráðu í menntunarfræðum frá Háskóla Íslands árið 2012. Rannsóknarsvið hennar eru meðal annars skóla- og frístundastarf, formleg og óformleg menntun, virk pátttaka og sjónarhorn barna.

Kolbeinn Hólmar Stefánsson er dósent í félagsfræði við félagsráðgjafardeild Háskóla Íslands. Hann lauk doktorsprófi í félagsfræði frá Oxford-háskóla árið 2013. Rannsóknarsvið Kolbeins beinast einkum að félagslegri lagskiptingu, lífsgæðum og jöfnuði, fátækt barna og gagnreyndri stefnumótun.

Hermína Gunnpórsdóttir (hermina@hi.is/hermina@unak.is) er prófessor við Menntavísindasvið Háskóla Íslands og kennaradeild Háskólans á Akureyri. Hún hefur starfað við leik-, grunn- og framhaldsskóla og lauk doktorsprófi frá Háskóla Íslands 2014. Helstu viðfangsefni hennar í kennslu og rannsóknum tengjast félagslegu réttlæti í menntun, skóla og námi án aðgreiningar, fjölmenningu og menntun, fötlunarfræði, menntastefnu og framkvæmd.

\section{About the authors}

Kolbrún P. Pálsdóttir (kolbrunp@hi.is) is an associate professor and dean of the School of Education at the University of Iceland. She completed a BA degree in philosophy in 1997, an MA in education in 2001 and a PhD in education from the University of Iceland in 2012. Her research areas include leisure centers, formal and informal education, active participation and young people's perspectives.

Kolbeinn Hólmar Stefánsson is an associate professor in sociology at the University of Iceland, department of social work. He graduated with a PhD in sociology from Oxford University in 2014. His research fields include social inequality, welfare and equity, children's poverty and informed policy making.

Hermína Gunnpórsdóttir (hermina@hi.is/hermina@unak.is) is a professor at the University of Iceland and University of Akureyri. She holds a PhD from the University of Iceland (2014). She has worked at kindergarten, primary and secondary schools. Her teaching and research interests relate to social justice in education, inclusive school and education, multiculturalism and education, disability studies, educational policy and practice. 


\section{Heimildir}

Allen, K., Kern, M. L., Vella-Brodrick, D., Hattie, J. og Waters, L. (2018). What schools need to know about fostering school belonging: A meta-analysis. Educational Psychological Review, 30(1), 1-34. https://doi.org/10.1007/s10648-016-9389-8

Allen, K., Vella-Brodrick, D. og Waters, L. (2017). School belonging and the role of social and emotional competencies in fostering an adolescent's sense of connectedness to their school. Í E. Frydenberg, A. J. Martin og R. J. Collie (ritstjórar), Social and emotional learning in Australia and the Asia-Pacific: Perspectives, programs and approaches (bls. 83-99). Springer.

Ársæll Már Arnarsson, Guðmundur T. Heimisson og Hermína Gunnpórsdóttir. (2019). Líðan í skóla og námsárangur: Niðurstöður úr rannsókninni Heilsa og líðan skólabarna (HBSC). Glaður, 29(1), $15-20$.

Ársæll Már Arnarsson, Sigrún Daníelsdóttir og Rafn Magnús Jónsson. (2020). Félagstengsl islenskra barna og ungmenna. https://www.landlaeknir.is/servlet/file/store93/item41614/F\%C3\%A9lagstengs $1 \% 20$ barna $\% 20$ og\%20ungmenna_LOK.pdf

Ársæll Már Arnarsson og Póroddur Bjarnason. (2020). Félagsleg staða og áfengisneysla unglinga 1999 og 2019: Niðurstöður úr rannsókninni Heilsa og líðan skólabarna (HBSC). Glaður, 30(1), $38-43$.

Áslaug Pálsdóttir, Bryndís B. Ásgeirsdóttir og Inga Dóra Sigfúsdóttir. (2012). Gender difference in well-being during school lessons among 10 to 12 year old children: The effects of school, family and peer related factors. Scandinavian Journal of Public Health, 40(7), 605-613. https://doi. org/10.1177/1403494812458846

Banks, J. A. (2020). Multicultural education: Characteristics and goals. Í J. A. Banks og C. A. M. Banks (ritstjórar), Multicultural education: Issues and perspectives (10. útgáfa, bls. 3-25). Wiley.

Borraccino, A., Berchialla, P., Dalmasso, P., Sciannameo, V., Vieno, A., Lazzeri, G., Charrier, L. og Lemma, P. (2020). Connectedness as a protective factor in immigrant youth: Results from the Health Behaviours in School-aged Children (HBSC) Italian study. International Journal of Public Health, 65(3), 303-312. https://doi.org/10.1007/s00038-020-01355-w

Christenson, S. L. og Reschly, A. L. (2010). Check \& connect: Enhancing school completion through student engagement. Í B. Doll, W. Pfohl og J. Yoon (ritstjórar), Handbook of youth prevention science (bls. 327-348). Routledge.

Damon, W. (2008). The path to purpose: How young people find their calling in life. Free Press.

Elgar, F. J., Pförtner, T.-K., Moor, I., De Clercq, B., Stevens, G. W. J. M. og Currie, C. (2015). Socioeconomic inequalities in adolescent health 2002-2010: A time-series analysis of 34 countries participating in the Health Behaviour in School-aged Children study. The Lancet, 385(9982), 20882095. https:doi.org/10.1016/S0140-6736(14)61460-4

Epstein, J. L. (2011). School, family, and community partnerships: Preparing educators and improving schools (2. útgáfa). Westview Press.

Gillen-O'Neel, C. og Fuligni, A. (2013). A longitudinal study of school belonging and academic motivation across high school. Child Development, 84(2), 678-692. https://doi.org/10.1111/j. 1467-8624.2012.01862.x

Goodenow, K. og Grady, K. E. (1993). The relationship of school belonging and friends' values to academic motivation among urban adolescent students. The Journal of Experimental Education, 62(1), 60-71. https://doi.org/10.1080/00220973.1993.9943831 
Hagstofa Íslands. (e.d.-a). Erlendir ríkisborgarar 1950-2019. https://px.hagstofa.is/pxis/pxweb/ is/Ibuar/Ibuar__mannfjoldi__3_bakgrunnur__Rikisfang/MAN04001.px/table/tableViewLayout1/?rxid=7960f499-7feb-4103-9337-12f024449320

Hagstofa Íslands. (e.d.-b). Mannfjöldi eftir menntunarstöðu samkvæmt ISCED 2011 2003-2020, hlutfallsleg skipting. https://px.hagstofa.is/pxis/pxweb/is/Samfelag/Samfelag__skolamal__5_menntunarstada/SKO00002.px/table/tableViewLayout1/?rxid=ffc9fa64-0b31-47f5-b72f-4d3091b58ffd

Hanna Ragnarsdóttir og Fríða B. Jónsdóttir. (2016). Aðgengi tví- og fjöltyngdra barna að menntun á Íslandi. Î Dóra S. Bjarnason, Hermína Gunnpórsdóttir og Ólafur Páll Jónsson (ritstjórar), Skóli margbreytileikans: Menntun og manngildi i kjölfar Salamanca (bls. 157-184). Háskólaútgáfan og Rannsóknastofa um skóla án aðgreiningar.

HBSC. (e.d.). Health Behaviour in School-Aged-Children. http://www.hbsc.org/

Hermína Gunnpórsdóttir og Lilja Rós Aradóttir. (2021). Pegar enginn er á móti er erfitt að vega salt: Reynsla nemenda af erlendum uppruna af íslenskum grunnskóla. Tímarit um uppeldi og menntun, 30(1), 51-70. https://doi.org/10.24270/tuuom.2021.30.3

Jóhanna Einarsdóttir og Sara Margrét Ólafsdóttir. (2020). Fullgildi í leikskóla: Sjónarmið barna og starfsfólks. Tímarit um uppeldi og menntun, 29(2), 113-131. https://doi.org/10.24270/tuuom.2020.29.6

Jón Gunnar Bernburg, Pórólfur Pórlindsson og Inga Dóra Sigfúsdóttir. (2009). Relative deprivation and adolescent outcomes in Iceland: A multilevel-test. Social Forces, 87(3), 1223-1250. https://doi. org/10.1353/sof.0.0177

Kolbeinn H. Stefánsson. (2019). Lifskjör og fátakt barna á Íslandi 2004-2016: Skýrsla unnin fyrir Velferðarvaktina. EDDA öndvegissetur.

Kolbrún P. Pálsdóttir. (2016). Hin hugsandi sjálfsvera: Formlegt og óformlegt nám skoðað í ljósi heimspeki Páls Skúlasonar. Sérrit Netlu 2016 - Menntun, mannvit og margbreytileiki. https://netla. hi.is/serrit/2016/menntun_mannvit_og_margbreytileiki_greinar_fra_menntakviku/009.pdf

Korpershoek, H., Canrinus, E. T., Fokkens-Bruinsma, M. og de Boer, H. (2020). The relationships between school belonging and students' motivational, social-emotional, behavioural, and academic outcomes in secondary education: A meta-analytic review. Research Papers in Education, 35(6), 641-680. https://doi.org/10.1080/02671522.2019.1615116

Kristjana Stella Blöndal og Atli Hafpórsson. (2018). Margbreytileiki brotthvarfsnemenda. Sérrit Netlu 2018 - Framhaldsskólinn i brennidepli. https://doi.org/10.24270/serritnetla.2019.11

Kristjana Stella Blöndal og Sigrún Aðalbjarnardóttir. (2009). Parenting practices and school dropout: A longitudinal study. Family Therapy, 36(3), 125-145.

Kristjana Stella Blöndal og Sigrún Aðalbjarnardóttir. (2014). Parenting in relation to school dropout through student engagement: A longitudinal study. Journal of Marriage and Family, 76(4), 778-795. https://doi.org/10.1111/jomf.12125

Laufey Dís Ragnarsdóttir, Álfgeir L. Kristjánsson, Ingibjörg Eva Pórisdóttir, Allegrante, J. P., Heiðdís Valdimarsdóttir, Steinunn Gestsdóttir og Inga Dóra Sigfúsdóttir. (2017). Cumulative risk over the early life course and its relation to academic achievement in childhood and early adolescence. Preventive Medicine, 96, 36-41. https://doi.org/10.1016/j.ypmed.2016.12.019

Lög um grunnskóla nr. 91/2008. 
Lög um sampættingu pjónustu í págu farsældar barna nr. 86/2021.

Main, G. og Bradshaw, J. (2016). Child poverty in the UK: Measures, prevalence and intrahousehold sharing. Critical Social Policy, 36(1), 36-81. https://doi.org/10.1177/0261018315602627

Margrét Lilja Guðmundsdóttir, Hrefna Pálsdóttir, Jón Sigfússon, Ingibjörg Eva Pórisdóttir, Erla María Tölgyes, Álfgeir Logi Kristjánsson og Inga Dóra Sigfúsdóttir. (2016). Ungt fólk 2016: Grunnskólar: Nám og skóli, félags- og tómstundastarf, ipróttir og hreyfing, foreldrar og uppeldi, heilsa og liðan, atvinnupátttaka og fjárhagur fjölskyldunnar og vímuefnanotkun ungmenna i 8., 9. og 10. bekk á Islandi: Samanburdur rannsókna árin 2000 til 2016: Staða og próun yfir tíma. Rannsóknir og greining.

Nieto, S. (2010). The light in their eyes: Creating multicultural learning communities (10. útgáfa). Teachers College Press.

OECD. (2019). PISA 2018 results (Volume III): What school life means for students' lives. https://doi. org/10.1787/acd78851-en

Páll Skúlason. (2015). Merking og tilgangur. Háskólaútgáfan.

Perry, D. G., Pauletti, R. E. og Cooper, P. J. (2019). Gender identity in childhood: A review of the literature. International Journal of Behavioral Development, 43(4), 289-304. https://doi. org/10.1177/0165025418811129

Pryor, L., Strandberg-Larsen, K., Andersen, A.-M. N., Rod, N. H. og Melchior, M. (2019). Trajectories of family poverty and children's mental health: Results from the Danish national birth cohort. Social Science \& Medicine, 220, 371-378. https://doi.org/10.1016/j.socscimed.2018.10.023

Ridge, T. (2002). Childhood poverty and social exclusion: From a child's perspective. The Policy Press.

Ridge, T. (2009). Living with poverty: A review of the literature on children's and families' experiences of poverty. Department for Work and Pensions.

Ridge, T. (2011). The everyday costs of poverty in childhood: A review of qualitative research exploring the lives and experiences of low-income children in the UK. Children \& Society, 25(1), 73-84. https://doi.org/10.1111/j.1099-0860.2010.00345.x

Uslu, F. og Gizir, S. (2017). School belonging of adolescents: The role of teacher-student relationships, peer relationships and family involvement. Educational Sciences: Theory \& Practice, 17(1), 63-82. https://doi.org/10.12738/estp.2017.1.0104

Pingskjal nr. 1111/2020-2021. Pingsályktun um menntastefnu fyrir árin 2021-2030. https:/www. althingi.is/altext/151/s/1111.html

Kolbrún P. Pálsdóttir, Kolbeinn H. Stefánsson og Hermína Gunnpórsdóttir. (2021).

Að tilheyra í skólanum: Áhrifapættir á upplifun grunnskólanema.

Netla - Veftímarit um uppeldi og menntun: Sérrit 2021 - HBSC og ESPAD rannsóknirnar

Sótt af http://netla.hi.is/serrit/2021/HBSC_ESPAD_rannsoknir/06.pdf

DOI: https://doi.org/10.24270/serritnetla.2021.10 